\title{
Religious Identity Politics on Social Media in Jakarta Gubernatorial Election 2017
}

\author{
Rahmad M. Arsyad ${ }^{1} \&$ Muhammad Asdar A.B. ${ }^{2}$ \\ ${ }^{1}$ Marketing Communication Program, Communication Department, Faculty of Economics \& Communication, \\ Bina Nusantara University, Jakarta, Indonesia \\ ${ }^{2}$ Postgraduate Communication Program, Fajar University, Makassar, Indonesia \\ Correspondence: Rahmad M. Arsyad. E-mail: rahmad.arsyad@binus.ac.id
}

Received: September 17, 2018

Accepted: October 11, 2018

Online Published: March 29, 2019

doi:10.5539/ass.v15n4p11

URL: https://doi.org/10.5539/ass.v15n4p11

\begin{abstract}
This study aims to examine the construction of religious identity politics discourse on Facebook and Twitter social media platforms on the 2017 Jakarta governor election. The researcher uses a constructive perspective by Paul C. Stern who views the use of identity politics as a construction formed from collaboration between the community and the political elite in creating tension and new conflicts in the country. The research methodology used focuses on the discourse of religious identity politics on social media (Facebook and Twitter) is a critical discourse analysis by Teun A Van Dijk. The results of this study revealed the construction of religious identity politics which was adopted in the form of symbolic power "Muslim Governor for Jakarta" as a form of reproduction of the majority discourse of privileges on minority groups.
\end{abstract}

Keywords: religious identity politics, social media, Jakarta gubernatorial election 2017, symbolic power majority privilege

\section{Introduction}

\subsection{Introduce the Problem}

The recent election of Jakarta Governor presents many social phenomena. The most prominent are the politics of religious identity in social media. It is in the form of spreading the Ulema fatwa, hoaxes, and slander about the haram and halal in choosing the governor candidate. All of these become public talks in the social media.

The heat in social media because of Jakarta gubernatorial election made Indonesia president, Jokowi, commented: "currently, when we open our social media, the content is full of blasphemy, mocking, cursing, and slander toward each other" (Ihsanudin, 2016).

The change of social media in Indonesia, from friendship network into the political-fight arena, is an old thing. Every election of the regional head to the positions of various social and political issues often makes social media as a debate arena between social media users. This situation sometimes ends with the breakup of friendship, or in social media term called unfollow or block.

Before the heat of discourse talks on social media about Jakarta gubernatorial election 2017, Indonesian had experienced this kind of events when social media became the arena of each presidential candidate's supporter to attack each other during the Presidential campaign in 2014.

At that time, there was a sharp rivalry between President Joko Widodo and Prabowo. Thus, social media became the arena of polarization and provocation between the two teams and two supporters of presidential candidates. Similar to the actual war, each pair of president and vice president candidates prepared Special Forces in social media.

The Jokowi-JK has a team called Jasmev, which stands for Jokowi-Ahok Social Media Volunteer and was previously a Jokowi-Ahok team in the Jakarta gubernatorial election. However, Prabowo-Hatta also formed an official social media team working for their coalition.

During the presidential election, sentiments based on the religious identity politics have also emerged. There was news about the background of President Jokowi that stated he is a Chinese, cannot perform ablution, and an anti-Islam. 
However, the escalation of religious identity politics is not as big as previous gubernatorial election. Basuki Tjahaya Purnama (Ahok), a non-Muslim candidate and his case that viewed as the blasphemy of Surah Al-Maidah 51 (Quran verse), has made a social media war about identity politics' tension higher.

The sentiments based on religious identity are not only happened in Jakarta but also at national and international level. There are debates, comments, and even attacks among each other on social media. It worried some parties that the condition would destroy the spirit of Indonesia diversity, which has been relatively maintained.

The presence of various discourses with religious sentiments has concerned various parties. Wahid Institute researcher, Alamsyah M Dja'far, assessed the spreading of hatred on social media as a symptom of hatred (Dja'far, 2015).

"Intolerance is the most visible symptom in social media so there must be an attempt to neutralize or respond to hate speeches in social media and to restrict the websites containing hate speech and those who spread intolerant messages ahead of the regional election or Presidential election."

According to Dja'far (2015), the spread of the intolerant messages tends to increase when it nears gubernatorial election or presidential election that loaded with political content in which social media become the place for opinion and discourse of rejection to those who are different.

The researcher explained that Wahid Institute is in line with Tempo's review regarding the headline "Anies-Sandi Religion and Sembako Factors." In the graphic info report, Tempo reviewed several survey results that religious identity politics are so strong in influencing factors.

For example, Indometric Survey Institute concluded that 60 per cent of the voters make the religious factor as the reason for choosing the governor. Furthermore, Tempo's review outlined the conclusions of Indonesian Polmark survey by Eep Saifulah Fatah that explained 67.7 per cent of Jakarta's voters chose Muslim leaders.

The polarization of religious sentiments as revealed by the latest research of the Indonesian Institute of Sciences (LIPI) through the Center for Political Studies (LIPI, 2017) is explained as a sign of the strengthening of identity politics that emerged from the public sphere, real or virtual.

Ridho Imawan Hanafi, a researcher of the Center for Political Studies LIPI, also conveyed, massive social media is used as an instrument of opinion mingling for winning candidates also influences the spread of hate speech, trigger provocation, and serious threat that will be faced in the journey of Indonesian democracy.

\subsection{Social Media as the Battle Arena of Political Discourse}

Some data showed that the growth of social media users in Indonesia is increasing over time. This condition is along with the increasingly widespread and mass internet usage in almost all levels of society.

The Ministry of Communications and Informatics in 2014 revealed that the internet users in Indonesia had reached 82 million people and 95 per cent of those people use the internet to access social media sites.

We Are Social (2015), a global social marketing agency, also explained the development of social media users in Indonesia. According to this site, the presence of smartphones triggered the explosion of active Internet users in Indonesia in which 62 per cent users accessed social media using mobile devices.

Moreover, this agency explained that three most widely accessed of social platform in Indonesia are Facebook, Whatsapp, and Twitter. Those social platforms are filled with the interaction among Indonesians.

The study result of Association of Indonesian Internet Service Users (APJI) specifically described the demographic of Internet users in each region. The Internet users in Jakarta reached 5.6 million people. This condition explains if the total population of Jakarta reaches 10 million people, half of Jakarta people are connected to the internet and the main social media are Facebook and Twitter.

The huge potential of social media user is the reason why social media is seen as campaign arena and influencing public opinion by the team of Jakarta governor candidate. It is especially the use of Twitter and Facebook as the top three social media platforms that become the interaction place of Jakarta people.

Moreover, the cheapness of the social media campaign becomes the second reason for the candidates use social media as a means of political campaigns compared to use conventional mass media, such as newspapers and televisions that have to pay huge fees to advertise.

Vergeer (2012), in his article entitled "Past, present and a peek into the future," said that the development of new media as a means of socializing political issues and campaigns will be a trend in the future. Now, it has happened not only in developed countries like America or Canada but developing countries like Indonesia. 


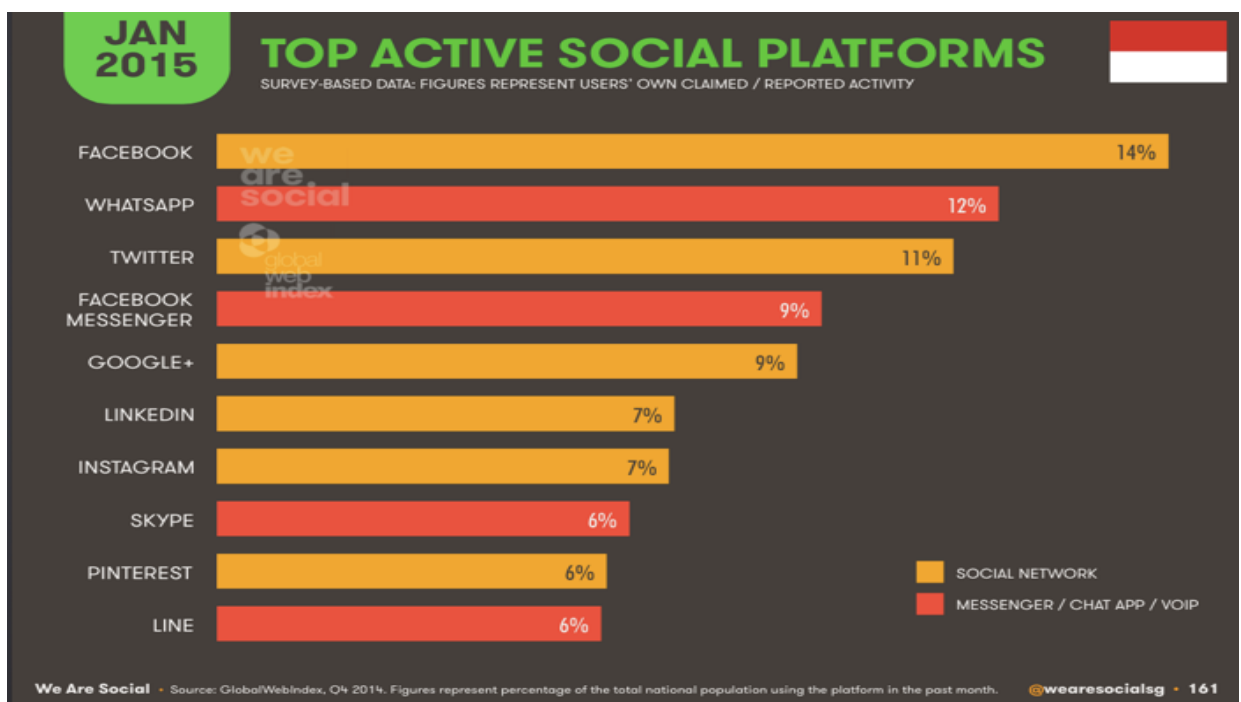

Figure 1. Top Ten Active Social Platforms in Indonesia (Source: We Are Social, 2015)

Greg Elmer's journal, "Live Research: Twittering an Election Debate" explained that perpetrators, consultants to political campaign researchers have a new challenge in following the development of how to communicate the community and the flow of public opinion, with the presence of leading social media platforms such as Blog, Facebook, and Twitter (2012).

According to Elmer (2012), the presence of social media sites gives a space and time to upload anything (including political campaigns) with relatively low cost. This condition has made many parties have to review the behavior of social media use with the current trend. The social media is not only a means of socialization of the candidate campaign program but becomes the arena of discourse battle which according to the researcher, it is a means of establishing the sentiments of religious identity politics.

\subsection{Research Problem}

Based on this phenomenon, this research focused on researching the construction of political discourse of religious identity in the election of Jakarta's regional head in the social networking arena of Facebook and Twitter, which should become the arena of friendship turned into a battleground of political discourse of religious identity.

\section{Theory and Research Method}

\subsection{The Battle of Religious Identity Politics in Political Arena}

The term of identity politics is simply used to describe a situation that characterized by the rise of identity groups in response to repression and marginalization in the past. Identity turned into identity politics when it becomes the basis of the marginalized group's aspiration struggle.

Stern in Pasic (1998) offered three typology perspectives for analysing conflict and violence, including nationalism and war as well as the rise of identity, both religious and ethnic.

First is the primordialist view. According to this view, the identity of ethnic culture, religion, race is stable, fixed, unchanged, and if it changing it will take a long time.

Second is instrumentalist view. This view understands cultural and religious identity as part of the practice of manipulation and mobilization of certain elites to achieve their political goals. Regarding the conflict, the instrumentalist view assumes that the occurrence of conflict is no more a mere consequence of the mobilization of ethnic and religious identity by certain elites. Thus, ethnic and religious are not the direct cause of conflict and violence.

Third is constructionist view that improves the first and second views. This third view can also be referred to as synthesis view because it emphasizes on collaboration between communities and political elites in creating conflict. Myths, history, locality, traditions and cultural symbols among ethnic and religious members are used by the elite to reconstruct a new communal identity that suits their ideals.

The researcher in this study used the third view when the identity was seen as construction used by political 
elites and some societies in creating ethnic identity sentiment in the political arena of Jakarta gubernatorial election through various constructs of discourse, history and religious symbols.

\subsection{Critical Discourse Analysis}

This research used Critical discourse analysis that focused on text, social cognition and context of popular conversations on social media, Twitter and Facebook. The conversation contained the political sentiments of religious identity in Jakarta governor election in 2017.

The critical discourse analysis model used Teun A Van Dijk approach (in Eriyanto, 2001), which emphasizes that the critical paradigm sees discourse as interaction history. Since discourse understood as an action, then discourse means a form of interaction.

Van Dijk explained discourse as an act of interaction that has several consequences. The consequences happened because discourse is seen as a purpose, whether to influence, argue, persuade, support, react, and other things.

Discourse is also understood as something that is consciously expressed, controlled, and not something out of control or expressed out of consciousness. Guy Cook (in Eriyanto, 2001) mentions three central things in discourse, which are:

1. Text. It is all forms of language, not just printed on paper sheets, but also all kinds of expressions of communication, speech, music, images, sound effects, images, etc.

2. Context. It includes all situations and things that are outside the text and affect the use of language, such as participants in the language, the situation in which the text is produced, the intended function, etc.

3. Discourse. It is interpreted as text and context together.

Van Dijk's model of text analysis techniques seeks to combine the three dimensions of discourse into one unity of analysis. Van Dijk's analysis model can be described as follows:

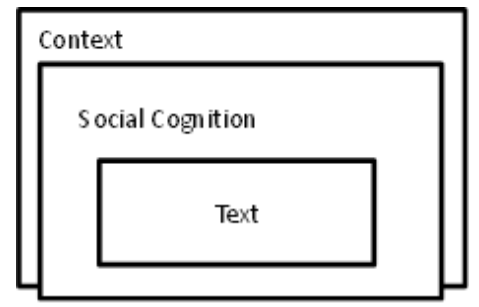

Figure 2. Teun A Van Dijk’s Discourse Analysis Model (Source: Eriyanto, 2001)

First, in the discourse analysis coined by Van Dijk, the text refers to the structure of text. Van Dijk utilizes and takes the linguistic analysis to interpret the text consisting of several structures/levels in which each part supports each other. Eriyanto (2001) gives an overview on the structure of the text according to Van Dijk.

Structure

\begin{tabular}{|l|}
\hline $\begin{array}{c}\text { Macrostructure } \\
\text { The global meaning of a text can be observed through its } \\
\text { topic/theme. }\end{array}$ \\
Superstructure \\
Text framework, such as introduction, content, closing, and \\
conclusion.
\end{tabular}

Figure 3. Teun A Van Dijk’s Discourse Analysis of Text (Source: Eriyanto, 2001) 
The text macrostructure is described by Van Dijk as the global meaning seen from a text containing the big picture of a text theme, and the text's superstructure is seen as the text framework consisted of each part. However, the microstructure is the local meaning of each text, either sentences or styles of a text.

In the second aspect, based on Van Dijk's explanation of social cognition stated that discourse analysis was not limited to the structure of the text. It is because the structure of discourse shows and signifies some meanings, opinions, and ideologies.

In covering hidden message in the text, cognition analysis is needed. Cognitive approach is based on the assumption that a text has no meaning, but the meaning is given by the language user, or rather the mental consciousness that forms the text. Third, in the context aspect, Van Dijk explains the importance of studying the constructing of discourse that develops in society of a text.

In this study, the text interpreted based on observations of various images, tweets, posts, Facebook status, and Twitter status. Whereas, social cognition is people's cognitive setting in posting and sharing texts that contained religious sentiments in social media and draw them in the context behind the ideology of the on-going religious identity discourse.

According to Van Dijk, critical discourse analysis has two important things, which are practice of power and individual power. Power can be a discourse as possession that owned by a group that dominates and continues to be reproduced by those in power, as a form of discrimination against other groups.

\subsection{Research Thinking Framework}

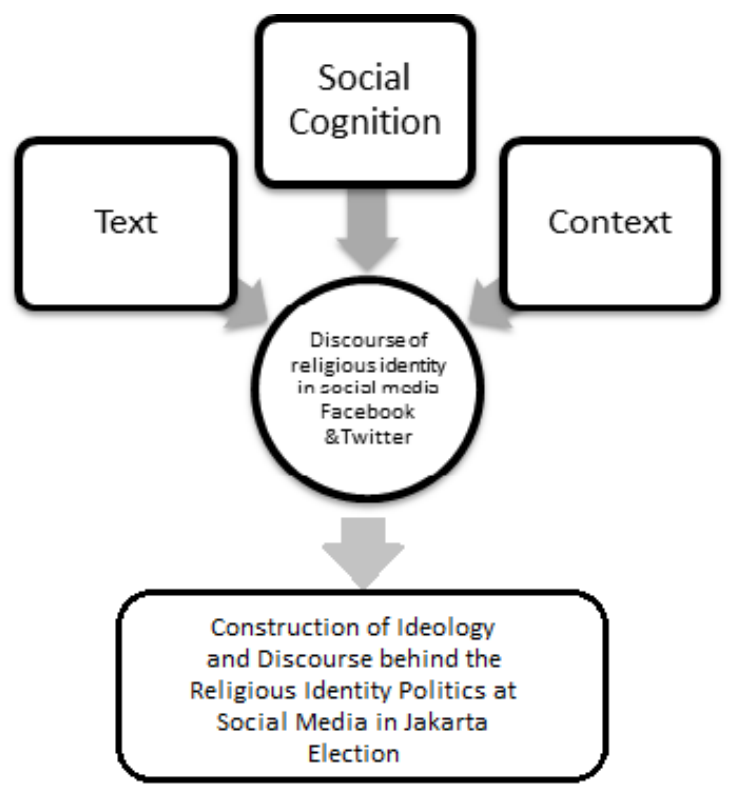

Figure 4. Research Framework

This study used critical discourse analysis by Van Dijk to see behind the discourse of religious identity politics on Facebook and Twitter. The researcher performed several stages following the existing research method.

First, collected the text in the form of status, statement, or Twitter's tweets that became trending on Facebook or Twitter and other groups that highlight the sentiment based on religious identity during the election campaign of Jakarta governor.

Second, to map social cognition and social context of those who actively post, disseminate, and produce texts of religious identity politics in the Jakarta governor election. The reason is to know the background of social cognition and social context, behind those who produce and spread the content of religious identity.

Third, explaining the production and reproduction of the arena of religious identity discourse battles on the social networking Facebook and Twitter during the election campaign of Jakarta governor and then drew the ideological construction behind the battle arena of religious identity politics on Facebook and Twitter.

\section{Research Results}

a. Jakarta Governor Election and Social Media War 
Twitter reflects the excitement of Jakarta governor election in 2017, which refers to the crucial moment. Based on Twitter's record (February 16, 2017), at the beginning of 2017, candidates for Jakarta governor election in 2017 used Twitter to share consistently information about their program to prospective voters and create interactions between them.

There are at least 11.2 million tweets associated with \#PilkadaSerentak2017. Since January 1, 2017, 1 million tweets were posted a day before the election. The results of Twitter reports noted that Jakarta elections into regional elections that have the biggest appeal on Twitter.

Throughout Jakarta governor election 2017, there are some popular hashtags such as \#voteAhok, \#AyoCoblosAgus, and \#coblospecinya that is Anies-Sandi's icon. Three candidate pairs of Jakarta governor actively use Twitter as a way of campaigning themselves and their programs.

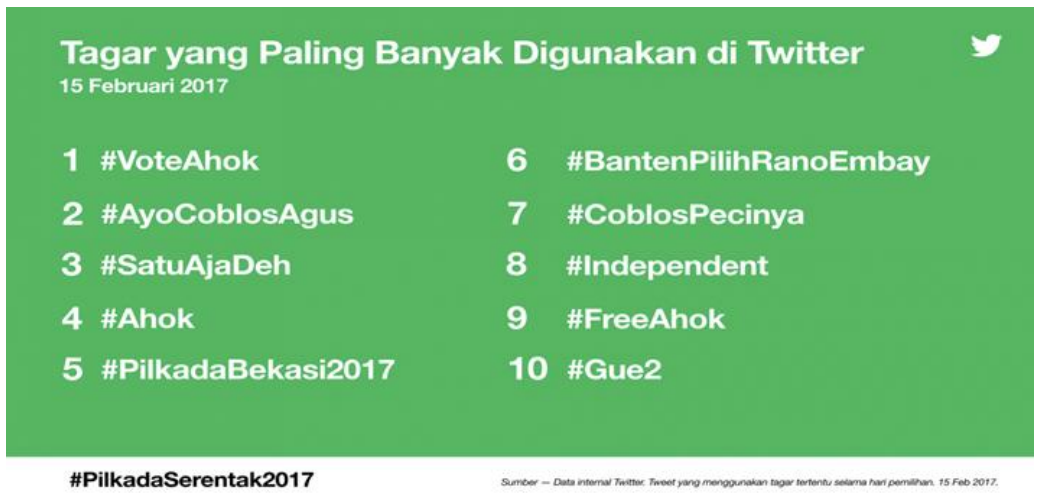

Figure 5. Most Popular Hashtag in Twitter

Source: Twitter Report (February 15, 2017)

Meanwhile, on Facebook, the debate is not less exciting. In contrast to Twitter in which it can classify popular hashtag, each candidate pair launched their respective fan page to capture voter support.

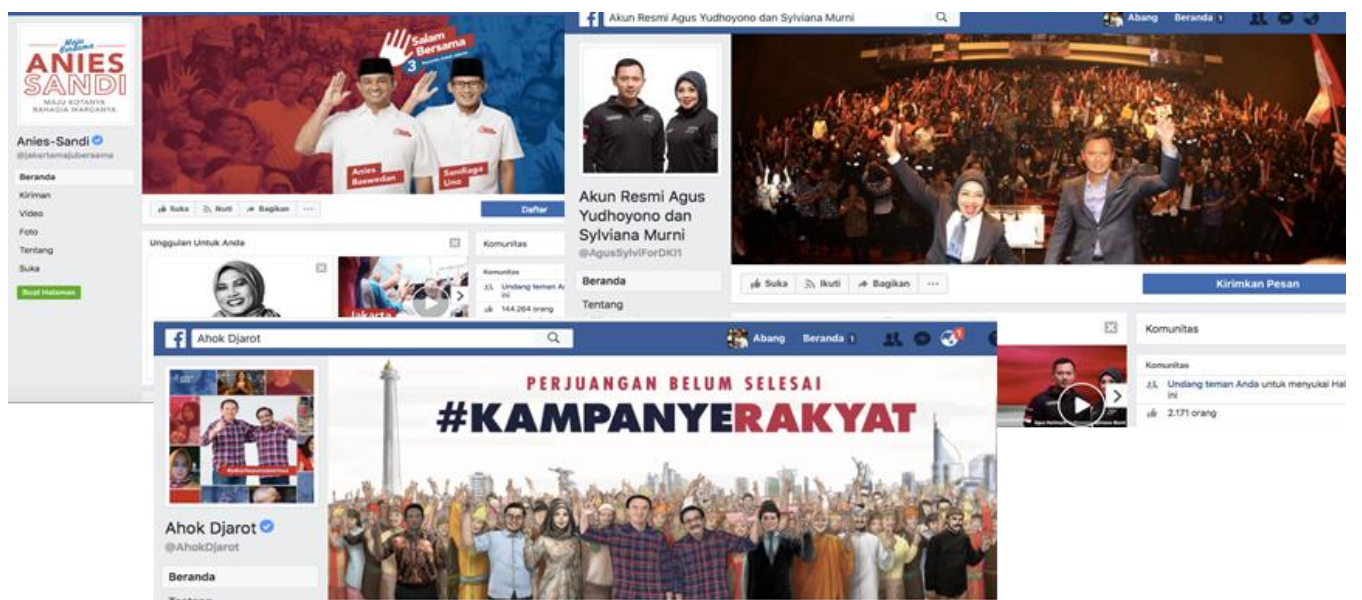

Figure 6. Facebook fan page of three candidate pairs of Jakarta governor 2017

Source: compiled by author (2017)

The analysis results of Provetic Jakarta (15/10/2016) explained that during the first round of campaign period in Facebook fan page, Ahok dominated with 1.224 million followers and surpassed the other candidates' followers. Also, Provetic Jakarta reported that based on the number of followers, Ahok tends to be very strong in Twitter with more than 5.744 million followers. Then, it followed by Anies Baswedan with 1.122 million followers, and Agus Harimurti Yudhoyono has 270 thousand followers.

Agus Harimurti Yudhoyono tends to be stronger in Instagram with the number of follower above 1,500 million, beating two other candidates. Not much different from the monitoring done by Provetic Jakarta, Ismail Fahmi, Founder of Media Kernels Indonesia (Batubara, 2015) who monitored conversations in social media also concluded that Basuki Tjahya Purnama was the most dominant candidate in social media talks.

PoliticalWave, a site that monitors sentiment index of social media talks as well as record netizen sentiments 
against both pairs of candidates for governor of Jakarta in the second round. The result, Ahok-Djarot grabbed 54.92 per cent positive sentiment and 45.08 per cent negative sentiment.

However, Anies-Sandi got 44.56 per cent positive sentiments and 55.46 per cent negative sentiments. PoliticalWave's mapping results that related negative issue of Ahok-Djarot are the issue of religious blasphemy, the insistence that Ahok to be non-active governor, 212 peaceful protest, and the defeat of several surveys.

Whereas, negative sentiments toward Anies-Sandi came from the criticism on the work program, alleged legal case, and alleged discrimination campaign as well as zero percent down-payment housing scheme. Based on those several facts, it appeared that Basuki Tjahya Purnama or Ahok tend to win in social media compared to other candidates.

The talks of Basuki-Djarot in social media, based on several surveys as revealed by Tempo.co (2017), apparently cannot do much to face the negative sentiments that arise from several hashtags and groups concerning religious identity which the tension became higher by bringing Ahok issue of blasphemy.

In the end, many researcher and several dominant surveys concluded that the main factor of voter reason is the same religious identity which became propaganda in social media.

b. Discourse Analysis of Texts Regarding Religious Identity Politics in Facebook and Twitter

The result of researcher's data collection that concerned several discourses on religious identity in social media (2016-2017), revealed some hashtags and popular posts on Twitter as well as several Facebook Groups that bring sentiment of religious identity since the beginning of the gubernatorial election.

The researcher found the average of Facebook Group that propagate the religious sentiment has average followers of 100,000 people and can reach hundreds or even thousands of conversations, for a single post on Facebook or Twitter.

Based on researcher finding, Table 1 shows five Facebook groups that most often post the sentiment of religious identity and hashtags or tweets about religious identity as well as the duty in choosing Muslim leader.

Table 1. Popular hashtags and groups that spread the sentiment of religious identity

\begin{tabular}{cc}
\hline Popular Hashtags of Religious Sentiment in Twitter & $\begin{array}{c}\text { Popular Facebook Groups Regarding the Sentiment of Religious } \\
\text { Identity }\end{array}$ \\
\hline \#muslimberSatupilihno1 & 100.000 .000 UMAT ISLAM-->> TOLAK PEMIMPIN KAFIR(AHOK \\
\#AniesSandiCintaUlama & DKK)DI INDONESIA \\
\#DjarotMuslimBTPKerja & Gubernur Muslim Utk Warga Jakarta \\
\#GubernurMuslim & GTA (gerakan Tolak Ahok) \\
\#BelaUlamaBuiBasuki & Sprit 411 dan 212 \\
\hline
\end{tabular}

The overview of macrostructure on discourse of religious identity politic text that emerged in social media, such as Facebook and Twitter, the majority confirmed a macrostructure of discourse "Muslim governor for Jakarta, let's unite to reject Ahok as disbeliever and anti-Ulema leader."

Various images of capture texts such as the Indonesian Ulema Council's Fatwa on Ahok's statement as a religious blasphemy, or comics about the duty of choosing Muslim leaders are scattered on the social media, both Facebook and Twitter. For example is Gubernur Muslim Untuk Jakarta group on Facebook and some anonymous Twitter accounts.

Based on the photo, text, and memes posted from the group discourse regarding the sentiments of religious identity on twitter and talks in Facebook groups, the suprastructure of discourse text can be described by the following model: 


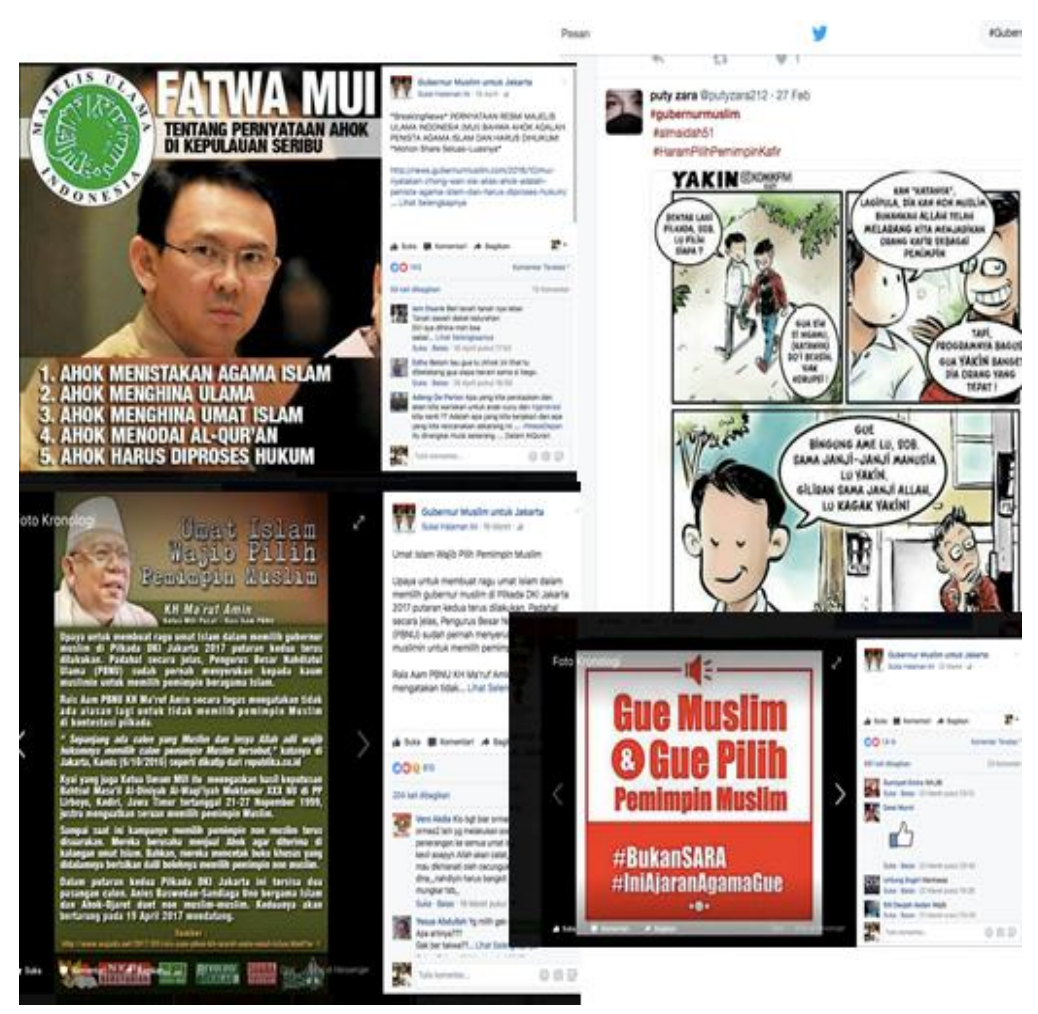

Figure 7. Meme, Comic and Capture of Discussion of Religious Identity Politics on Facebook and Twitter

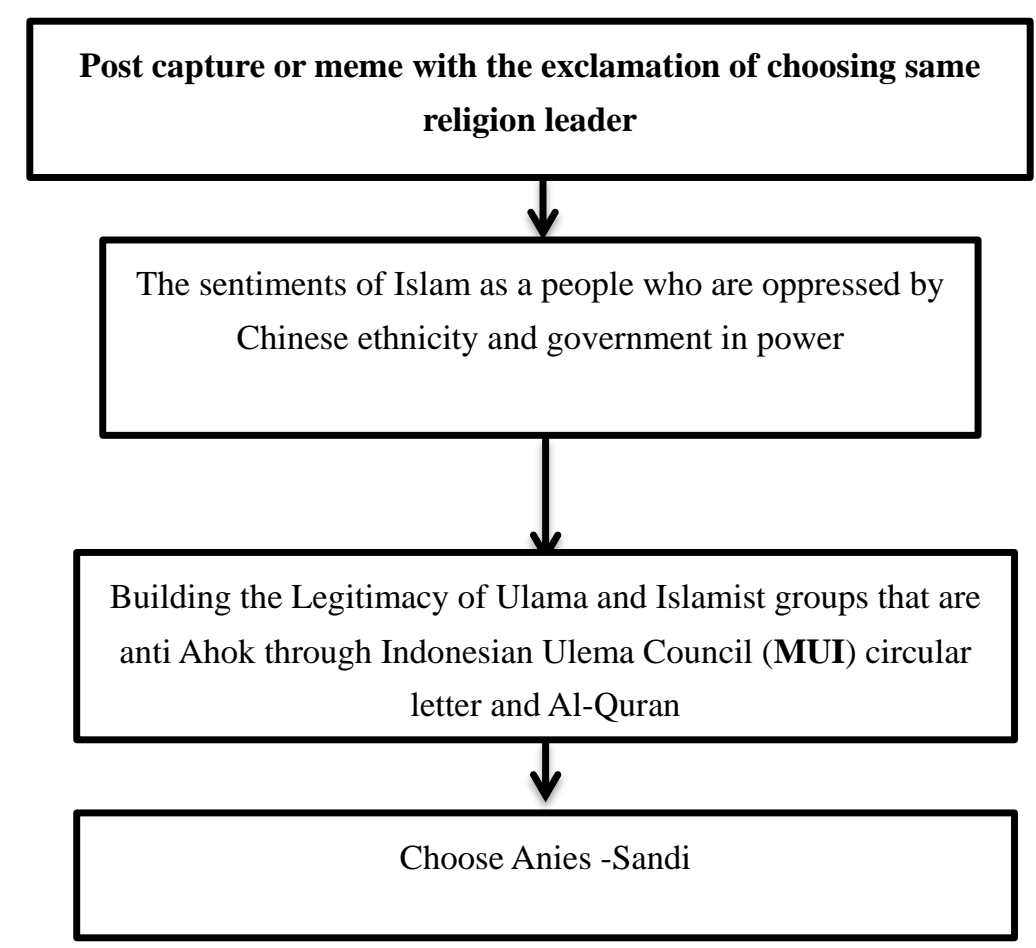

Figure 8. Flow of Suprastructure Discourse Text of Religious Identity Sentiment on Facebook Group and Twitter

The analysis result of suprastructure of religious identity discourse conducted by researchers in social media found a pattern. 
First, the majority of sentimental text of religious identity discourse begins from the posting of group accounts in the form of capture of MUI fatwa, and then continued the verse about the duty of choosing Muslim leader or meme with the message of "I am Muslim, and I choose Muslim Leader."

Second, after the topic is commented or retweeted then the conversation will raise a provocative tone by group members that during this time Muslims are oppressed by ethnic Chinese and government in power. Furthermore, various verses and calls for choosing Muslim governors are distributed, if there is a contradiction, then it will collectively get provocative replies by establishing the legitimacy of some verses of Al-Quran and leadership interpretation.

Thirdly, after the discussion continues, ultimately the account manager or those who are distributing the Muslim leader's tag will soon post a photo or picture of the candidate of Muslim governor both Anies-Sandi and Agus-Syilvi as a solution to the unity of community.

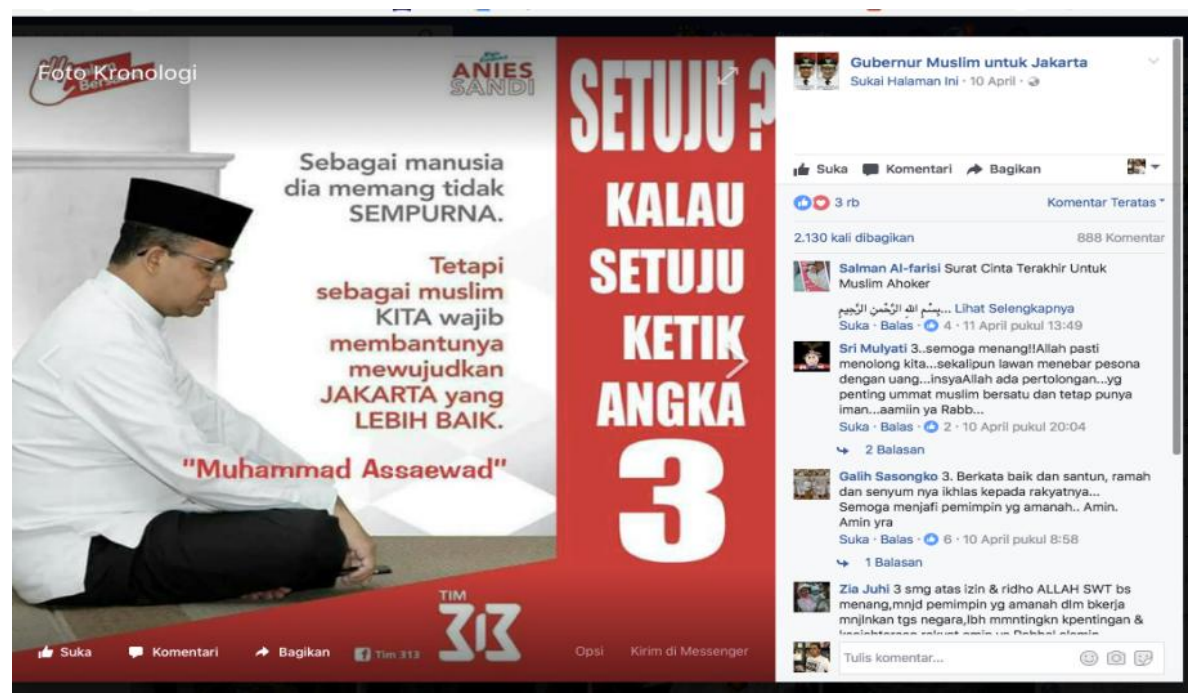

Figure 9. One of captures of Jakarta Muslim Governor

Source: Facebook Group of Gubernur Muslim Jakarta

Based on the discourse superstructure pattern, as viewed from the microstructure of discourses that build on Facebook and Twitter, the discourse was carrying a single message that is "the unity of Muslims to elect the Muslim governor."

The construction of discourse is part of political communication style that aimed at building a propaganda-based solidarity. The use of propaganda language in political communication in the explanation of Nimmo (2004) is described as an effort to form the beliefs and attitudes of group members.

Ellul (1973) explained that the propaganda language of communication used by an organized group that wants to create active or passive participation in actions consisting of individuals is psychologically integrated through psychological manipulation and incorporated into the same organization or association.

The analysis results of the suprastructure discourse and the pattern of meaning on the on-going microstructure found that the sentiments of religious identity discourse attack voters' psychology with targets as what Dann Nimo explained, build solidarity with the identity group members as fellow Muslims to vote Muslim governor.

\section{c. Cognition and Context of Identity Politics on Social Media of Jakarta Gubernatorial Election}

The identification result of individual and group that often post image, news, and tweets in Twitter that bring sentiment-based religious identity from research result, it was found that the background of social cognition source is divided into two types of identity. First is an anonymous account group with no clear identity. Second is a group member of Islamic organizations which since the beginning expressed opposition to Ahok.

Based on Figure 9, Twitter account of jawarabetawi411 that diligently posts the necessity of choosing Muslim governor is an anonymous account while in the other picture, the FPI Facebook group on March 22, 2016, expressed the rejection of the infidel leader. 

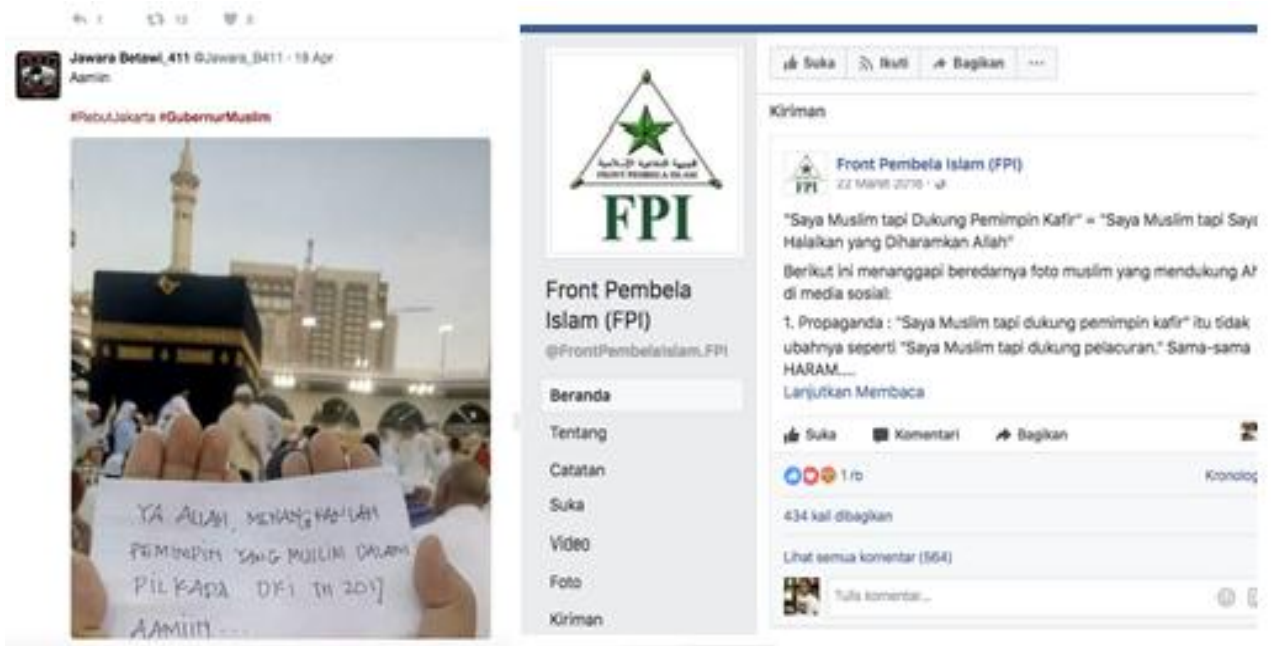

Figure 10. Account that spread the sentiment of religious Identity (anonymous and organization)

Ismail Fahmi, the Founder of Media Kernels Indonesia (Batubara, 2017) also expressed the solidarity on Jakarta Gubernatorial election was a widespread solidarity as a result of the observation of Jakarta election discussion when the public debate occurred. The result was 45 per cent of the conversation of the second Jakarta election debate comes from Jakarta and as much as per cent from outside Jakarta.
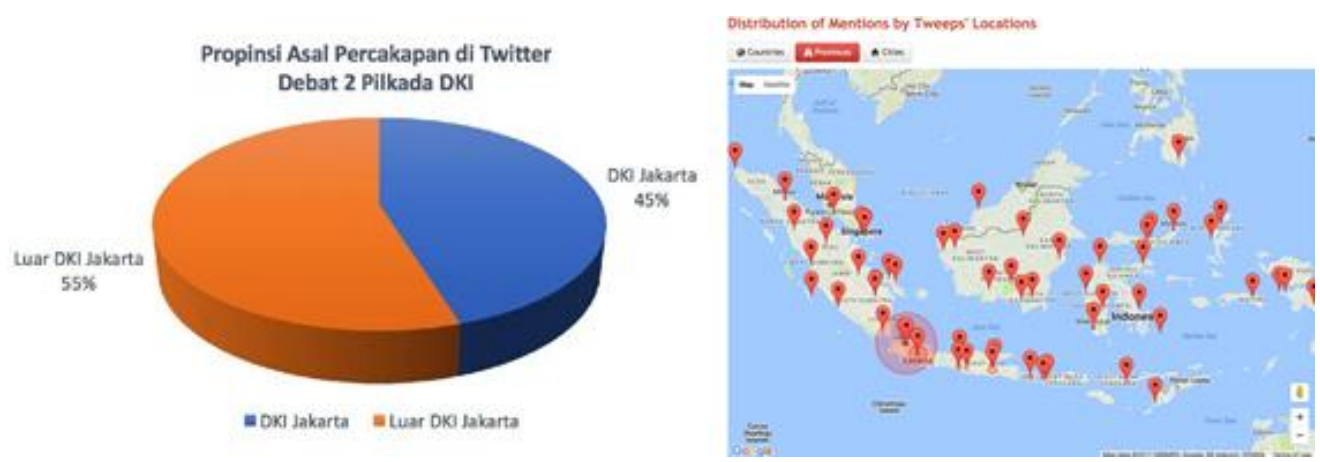

Figure 11. Conversation source of Jakarta Gubernatorial Election 2017

Ismail Fahmi's finding explained that Jakarta gubernatorial election 2017 has succeeded in building collective solidarity where they who commented about Jakarta gubernatorial election 2017 are mostly from outside Jakarta.

It cannot be disregarded that the social media battle on religious identity also builds national solidarity including public pressure on Jakarta voters to agree to vote for leaders on the basis of the same identity solidarity, "I am Muslim I have to elect a Muslim governor, let's Muslim be united."

\section{d. Ideology Construction behind the Discourse of Religious Identity Politics in Jakarta Gubernatorial Election}

Stern's view (1998) concerns the relation of religious identity discourse battle in social media on Jakarta gubernatorial election. Based on the constructionist perspective from the result of Van Dijk's critical discourse analysis, it can be explained that there are several related models of discourse battle of religious identity politics in social media such as Facebook and Twitter.

First, religious politic identity was used in social media by building psychology sentiments of Jakarta people through macrostructure of dominant structure "Muslim governor for Jakarta. Let's reject Ahok as a disbeliever and anti-Ulema leader."

This macro discourse theme presented as an effort to build group solidarity through various pictures, texts, and tweets for propaganda based on religious identity. Also, building the collective spirit of group that has been 
experiencing repression and pressure of power.

The mental as the wounded majority deliberately built through the social media discourse of Twitter and Facebook by anonymous groups and ranks of organizations that reject Ahok, with the main target of building a collective solidarity to elect fellow Muslim leaders.

Paul C. Stern explanation that identity politics as a synthesis and collaboration between society and the political elite in creating conflict is real in which the symbol between religious communities are used by the elite to reconstruct the same unity of identity that is "fellow Muslims" and disseminated by some people as an absolute.

Stuart Hall (1997) asserted that one's identity cannot be separated from "the sense of collective awareness." When identity is formulated as something that makes a person has similarity with others, then at the same time, identity also formulates the otherness or something beyond those similarities.

The emergence of 'fellow Muslim' term was conducted to build differences and the dichotomy of "we are Muslim" and "people who choose Ahok is non-Muslim or misguided Muslim. Thus, this identity construction is the root of problem in the social media area and the gubernatorial election.

Identity is shaped into a mythology that forms an affiliation and political mobilization. Then, it breeds social prejudice, power sharing, and even segregation to the extreme situation of giving birth to discrimination among those who are referred to as "our" and "those who are not part of us."

In fact, the essence of direct gubernatorial election is the democracy arena for the public to give birth to leadership based on integrity and ability in organizing social life in society, not built on differences or based on the principle of maintaining dominance and identity of majority rule.

Second, through the reproduction of texts by the legitimacy of Ulema and Qur'an verses, and the obligation to elect Anies-Sandi as a candidate for Muslim governorship, are how non-supporters groups of Ahok, both of anonymous group and community organizations, build the propaganda of political communication.

The emergence of the political sentiments of identity (Lippmann in Rogers, 1994) is strongly influenced by using stereotype, which became the code of reality and then became a reference source to convince individuals.

The presence of stereotyped languages such as "infidel leader" or "religious blasphemy" is a way of building symbolic power. Similarly, the label of "Muslim leader" is a way to maintain symbolic power that invisible and recognizable from the purpose to gain power.

Symbolic power works by using its main symbol, which is through language as an instrument of representation from the running of its power either by using rational political communication or by propaganda language in the name of a Muslim identity or Muslim leader.

In political communication, language usage determines a particular format of narration (and meaning). Fiske (1990), in Cultural and Communication Studies, added that the use of certain languages has implications for the construction of reality and the meaning.

The choice of words and ways of presenting a reality contributes to the construction structure of reality and meaning that emerged. From this perspective, language is not only able to reflect reality but also create reality. If we see the discourse used in the Jakarta election, especially the second round, it builds two great dichotomies "to be Muslim" or "unbecoming Muslim." This is what is called "language is power!." It is because through the language, power is interpreted as an effort to produce and display the world view that is the most recognized, the most correct, and the most legitimate.

Third, based on macro text and micro text structure as well as the construction of social discourse and cognition in Facebook and Twitter, it can be explained that the ideological background behind the discourse battle is the effort to maintain the majority of the privilege. This becomes the primordial consequences that must be accepted by those who are constructed as a minority.

The ideological overview is visible to the discourse structure built with the projection of power of Muslim Governor. This is part of the deliberate power to build discriminatory discourse to minority groups.

This process described by Howertz (in Bascova, 1998) as the construction and instrumentalism media of political elite in mobilizing their political interest. Identity politics is a strict line-up to determine who will be included and who will be rejected. The borderline cannot be changed, so the status as member or non-member appears to be permanent.

Moreover, Howertz (in Bascova, 1998) assumed that the minority would tend to be used as a profitable tool for the majority. Thus, the categories are based on the interests of political elites, including various types of 
propaganda on Facebook and Twitter during Jakarta gubernatorial election 2017 about the discourse of the Muslim governor.

\section{Conclusion}

Based on the conclusion of research results, the model of production and reproduction of text in social media, Facebook and Twitter, can be explained. So, the construction of religious identity politics that rose in the discourse of social media, both Facebook and Twitter, dominantly brings one big theme, which is the power of discourse "Muslim Governor for Jakarta."

The process of production and reproduction of the discourse is constructed by political groups of both individuals and some community organizations which since the beginning reject Ahok. This condition is a form of the power of majority privilege rules over minority groups. The aim is to reinforce the ideology of majority rule over minorities

\section{References}

Bacova, V. (1998). The Construction of National Identity on Primordialism and Instrumentalism. Human Affairs, 8, 29-43

Batubara, H. (2017, January 28). 55\% Percakapan soal Pilgub di Twitter Berasal dari Luar DKI. Retrieved from https://news.detik.com/berita/d-3407911/55-percakapan-soal-pilgub-di-twitter-berasal-dari-luar-dki

Dja'far, A. M. (2015, May 22). Pilkada Serentak dan Ancaman Kebencian. Retrieved from http://nasional.kompas.com/read/2015/05/22/15010011/unpad?page=all

Ellul, J. (2013). Propaganda: The Formation of Men's Attitudes (Trans: K. Kellen \& J. Lerner). New York: Vintage Books.

Elmer, G. (2013). Live research: Twittering an election debate. New media \& society, 15(1).

Eriyanto. (2011). Analisis Teks Media. Yogyakarta: LKiS.

Hall, S. (2013). Representation: Cultural Representation and Signifiying Practices. Sage Publishing.

Ihsanudin. (2016, November 9). Jokowi Prihatin Masyarakat Saling Hujat di Media Sosial. Retrieved from http://nasional.kompas.com/read/2016/11/09/11245931/jokowi.lagi-lagi.kritisi.pengguna.medsos.yang.salin g.cela.dan.hujat

Indonesia Institute of Science (LIPI). (2017, May 3). LIPI Paparkan Hasil Riset dan Analisis Pilkada Jakarta 2017. Retrieved from http://lipi.go.id/siaranpress/LIPI-Paparkan-Hasil-Riset-dan-Analisis-Pilkada-Jakarta2017/18099

Metro. (2017, April 15). Political Wave: Ahok-Djarot Pilihan Netizen. Retrieved from http://pilkada.metrotvnews. com/news-pilkada/3NO0ZWmb-politicalwave-ahok-djarot-pilihan-netizen

Nimmo, D. (2004). Komunikasi Politik, Khalayak dan Efek. Jakarta: Rosda Karya.

Pasic, A. (1998). Culture, Identity, and Security: An Overview (pp. 9-11). New York: Rockefeller Brothers Fund.

Vergeer, M. (2012). Politics, elections and online campaigning: Past, present and a peek into the future. New Media and Society, 15(1).

We Are Social, Digital, Social \& Mobile in 2015. (2015, January 21). Retrieved from https://wearesocial.com/sg/special-reports/digital-social-mobile-2015

\section{Copyrights}

Copyright for this article is retained by the author(s), with first publication rights granted to the journal.

This is an open-access article distributed under the terms and conditions of the Creative Commons Attribution license (http://creativecommons.org/licenses/by/4.0/). 